\title{
Evaluation of micronutrient status of soils and their relation with some chemical properties of soils of Wardha district, Maharashtra
}

\section{YOGITAD. GORE, NILIMAS. SADANSHIV AND N. S. WAGH}

Received : 15.09.2017; Revised : 07.11.2017; Accepted : 17.11.2017

MEMBERS OF RESEARCH FORUM:
Corresponding author :
YOGITA D. GORE, Department
of Soil Science and Agricultural
Chemistry, Dr. Panjabrao Deshmukh
Krishi Vidyapeeth, AKOLA (M.S)
INDIA

Co-authors : NILIMA S. SADANSHIV AND N. S. WAGH, Department of Soil Science and Agricultural Chemistry, Dr. Panjabrao Deshmukh Krishi Vidyapeeth, AKOLA (M.S) INDIA

Email: nil.sadanshiv@gmail.com; nwagh98@gmail.com

\begin{abstract}
Summary
The present investigation was carried out for evaluation of the status of DTPA- Fe, Mn, Cu and $\mathrm{Zn}$ in relation with physico-chemical properties in soils of Wardha district. Total 75 surface soil samples were collected and analysed for soil properties and fertility status of study area. The results revealed that the soils are neutral to strongly alkaline in soil reaction, safe in electrical conductivity, low to high in organic carbon content and high cation exchange capacity.Soils were sufficient in DTPA-extractable micronutrient cations except zinc which was found deficient in nearly 44 per cent of the samples. Pearson correlation co-efficients indicated positive correlation of DTPA- extractable micronutrient cations with organic carbon and negative correlation with $\mathrm{pH}, \mathrm{EC}$ and no significant relationship of DTPA-Mn, $\mathrm{Cu}, \mathrm{Zn}$ was found with CEC.
\end{abstract}

Key words : Soil fertility, DTPA-extractable micronutrient

How to cite this article : Gore, Yogita D., Sadanshiv, Nilima S. and Wagh, N.S. (2017). Evaluation of micronutrient status of soils and their relation with some chemical properties of soils of Wardha district, Maharashtra. Asian J. Soil Sci., 12 (2) : 271-274 : DOI : 10.15740/HAS/AJSS/12.2/271-274. 